\title{
Allometric models for estimating the leaf area of lisianthus (Eustoma grandiflorum) using a non-destructive method
}

\author{
Marlon Gomes Dias ${ }^{l \dagger}$, Toshik Iarley da Silva ${ }^{1+*} * \mathbb{D}$, João Everthon da Silva Ribeiro ${ }^{2}$, \\ José Antônio Saraiva Grossi ${ }^{l}$, José Geraldo Barbosa ${ }^{l}$
}

10.1590/0034-737X202269010002

\begin{abstract}
Lisianthus (Eustoma grandiflorum) is a cut flower grown due to the wide diversity of colors and longevity in the post-harvest. The leaf area measurement is fundamental in plants because the leaves are directly related to several processes such as transpiration, radiation interception and $\mathrm{CO}_{2}$ fixation that enable the plant to grow. The objective of the work was to determine an allometric equation for estimating the leaf area of lisianthus from linear dimensions. 200 leaves were collected and the leaf length (L), leaf width (W), product between length and width (LW) and real leaf area (LA) were measured. The criteria for determining the best model were the highest determination coefficient $\left(\mathrm{R}^{2}\right)$, Willmott's concordance index $(d)$, lowest Akaike information criterion (AIC), root mean square error (RMSE) and BIAS index closest to zero. The most suitable model for estimating the leaf area of lisianthus is the linear $\mathrm{w}=1.387 * \mathrm{LW}$.
\end{abstract}

Keywords: Ornamental plants; Leaf dimension; Leaf area measurement.

\section{INTRODUCTION}

Lisianthus [Eustoma grandiflorum (Raf.) Shinners] is an ornamental plant appreciated for its delicate flowers. Lisianthus is an annual herbaceous plant originating from the pastures of the North American prairies, with height varying between 15 to $60 \mathrm{~cm}$, with bluish green leaves, large flowers grow in a tapered form on straight stems with their petals increasing in size (Castillo-González et al., 2017). This plant is grown as a cut flower due to its wide color palette and also because of its long post-harvest life. It is also used as a plant for pots and flower beds in gardens (Bertoldo et al., 2015).

Studies to evaluate the growth, development and reproduction of plants are needed, due to economic importance of this species. Among these studies, the leaf area measurement is of fundamental importance, since the leaves are directly related to processes such as evapotranspiration, radiation interception and $\mathrm{CO}_{2}$ fixation (Hernandez-Santana et al., 2017), as well as obtaining several physiological variables, such as specific leaf area, leaf area ratio, net photosynthesis rate, leaf area index and leaf weight ratio, frequently used in plant growth analysis (Maia et al., 2020).

The leaf area measurement can be performed directly or indirectly, using destructive and non-destructive methods (Mattos et al., 2020). Destructive methods, even showing efficiency, limit the development of the plant because it hinders the growth and the crop cycle, in addition to requiring more labor (Schmildt et al., 2014). The leaf area when measured by the direct and nondestructive method, despite not presenting any difficulty, depends on high cost equipment, while the indirect and non-destructive methods allow successive evaluations of the same plant by means of allometric equations, which are adjusted using the linear dimensions of the leaves, providing speed and precision in the evaluations (Toebe et al., 2012).

The statistical modeling obtained by allometric leaf equations has been widely used in other cultivated species, such as Mucuna cinerea (Cargnelutti et al.,

\footnotetext{
Submitted on December $10^{\text {th }}, 2020$ and accepted on March 23 $3^{\text {th }}, 2021$.

${ }^{1}$ Universidade Federal de Viçosa, Departamento de Agronomia, Viçosa, Minas Gerais, Brazil. toshik.silva@ufv.br; marlon.dias@ufv.br; jgrossi@ufv.br; jgeraldo@ufv.br

${ }^{2}$ Universidade Federal da Paraíba, Departamento de Fitotecnia e Ciências Ambientais, Areia, Paraíba, Brazil. j.everthon@hotmail.com.

*Corresponding author: toshik.silva@ufv.br
} 
2012b), Canavalia ensiformis (Toebe et al., 2012), Passiflora edulis (Morgado et al., 2013), Coffea arabica (Schmildt et al., 2014), Ananas comosus (Francisco et al., 2014), Fragaria x ananassa (Zeist et al., 2014), Mangifera indica (Silva et al., 2015), Macadamia integrifolia (Schmildt et al., 2016), Glycine max (Souza et al., 2019), Malpighia emarginata (Azevedo et al., 2019) and Theobroma cacao (Schmildt et al., 2017). With this, the objective of the work was to determine an allometric equation for estimating the leaf area of lisianthus from linear dimensions.

\section{MATERIAL AND METHODS}

The research was carried out in the Unidade de Ensino, Pesquisa e Extensão - Floricultura, at the Universidade Federal de Viçosa, Minas Gerais, Brazil. 20 leaves of

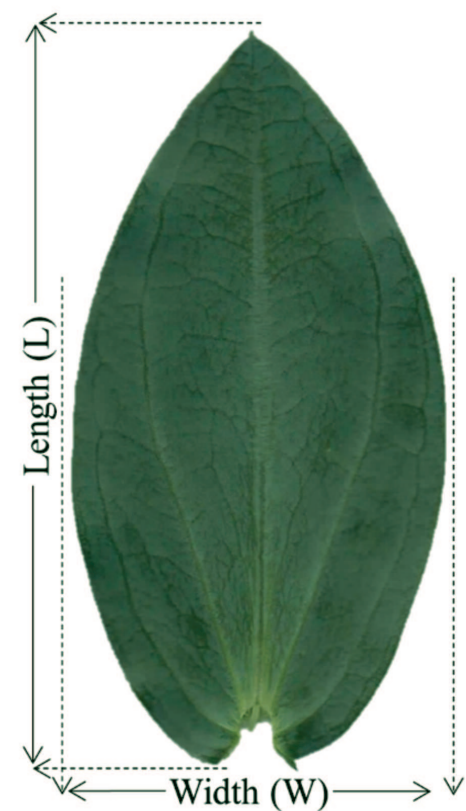

Figure 1: Maximum length (L) and width (W) of leaf of Eustoma grandiflorum and used to estimate leaf area. different sizes were collected from 10 plants, totaling 200 leaves (Schwab et al., 2014; Ribeiro et al., 2020). The leaves had no deformities originating from external factors (healthy leaves), such as pests or diseases.

The leaf length (L) and leaf width (W) (Figure 1) were measured from images digitized on a flatbed scanner (Epson Scan I365), added with a known scale. From these data, the product of length and width (LW) was calculated. The measurements of the real leaf area were performed with the aid of the Image ${ }^{\circledR}$ software (Powerful Image Analysis), in which the images were contrasted to facilitate the measurements (Ribeiro et al., 2018).

A descriptive analysis to obtain the maximum and minimum values, mean, median, total amplitude, variance, standard deviation, standard error, coefficient of variation and coefficients of asymmetry and kurtosis was performed from the data of leaf length (L), leaf width (W), product (LW) and real leaf area (LA). Regression studies were performed to choose the equation that satisfactorily estimated the leaf area of lisanthus. The statistical models were: linear, linear without intercept (0.0), quadratic, cubic, power and exponential. The $\mathrm{Y}$ value was estimated for $\mathrm{X}$, whose values were those represented by length $(\mathrm{L})$, width (W) or product $(\mathrm{LxW})$. The best equations were chosen based on the highest determination coefficient $\left(\mathrm{R}^{2}\right)$ and Willmott's agreement index (d) (Willmott et al., 1981), lowest Akaike information criterion (AIC) (Akaike, 1974) and root mean square error (RMSE) (Janssen \& Heuberger, 1995 ) and BIAS index closer to zero (Leite \& Andrade, 2002). Statistical analyzes were performed using the $R$ software (R Core Team, 2020).

\section{RESULTS AND DISCUSSION}

The observed data had variation, where the minimum and maximum values for leaf length (L) were 1.437 and $15.166 \mathrm{~cm}$, with an average of 8.691 and $13.729 \mathrm{~cm}$ of amplitude. The leaf width (W) had values between $0.182 \mathrm{~cm}$ and $10.433 \mathrm{~cm}$, average of $4.500 \mathrm{~cm}$ and amplitude of 10.251

Table 1: Minimum, maximum, mean, median, standard deviation, standard error, and coefficient of variation (C.V.), asymmetry and kurtosis for length (L), width (W), length by width (LxW) and leaf area (LA) of Eustoma grandiflorum leaves

\begin{tabular}{lcccc}
\hline Descriptive statistic & $\mathbf{L}(\mathbf{c m})$ & $\mathbf{W}(\mathbf{c m})$ & $\mathbf{L W}\left(\mathbf{c m}^{2}\right)$ & $\mathbf{L A}\left(\mathbf{c m}^{2}\right)$ \\
\hline Minimum & 1.437 & 0.182 & 0.442 & 1.152 \\
Maximum & 15.166 & 10.433 & 142.337 & 189.733 \\
Mean & 8.6919 & 4.5004 & 45.0852 & 64.5842 \\
Median & 8.951 & 4.298 & 37.962 & 57.3925 \\
Total amplitude & 13.729 & 10.251 & 141.895 & 188.581 \\
Variance & 11.2238 & 4.3778 & 1023.111 & 1749.541 \\
Standard deviation & 3.3502 & 2.0923 & 31.9861 & 41.8275 \\
Standard error & 0.2369 & 0.1479 & 2.2618 & 2.9577 \\
C.V. $(\%)$ & 38.54 & 46.49 & 70.95 & 64.76 \\
Asymmetry & -0.3547 & 0.2442 & 0.6765 & 0.4815 \\
Kurtosis & -0.6341 & -0.3501 & -0.2418 & -0.4107 \\
\hline
\end{tabular}

Rev. Ceres, Viçosa, v. 69, n.1, p. 007-012, jan/feb, 2022 
$\mathrm{cm}$. The product of length and width (LW) varied from 0.442 to $142.337 \mathrm{~cm}^{2}$, with $45.0852 \mathrm{~cm}^{2}$ of average and amplitude of $141.895 \mathrm{~cm}^{2}$ (Table 1). High standard deviations related to the averages obtained can be attributed to the varied sizes of leaf sizes (Silva et al., 2017).

The scatter plots between the pairs of variables L, W, LW and LA showed different relationships between each other, suggesting adjustments of linear and non-linear models (Figure 2).

The leaf area varied from 1.152 to $189.733 \mathrm{~cm}^{2}$, with a higher percentage of leaves $(22.5 \%)$ in the range between 40.01 and $60.00 \mathrm{~cm}^{2}$ (Table 2). However, the area values and their percentage were well distributed. This is due to the fact that the lisianthus plant has different leaf sizes, which is the analysis with accuracy and good data distribution. The high amplitude values are important because they represent the leaf area using statistical models by regression analysis. When using regression analysis to estimate the values of the independent variable, the values used in the construction of the regression equation should not be extrapolated as soon as the requirements have been attended (Levine et al., 2012; Schmildt et al., 2017).
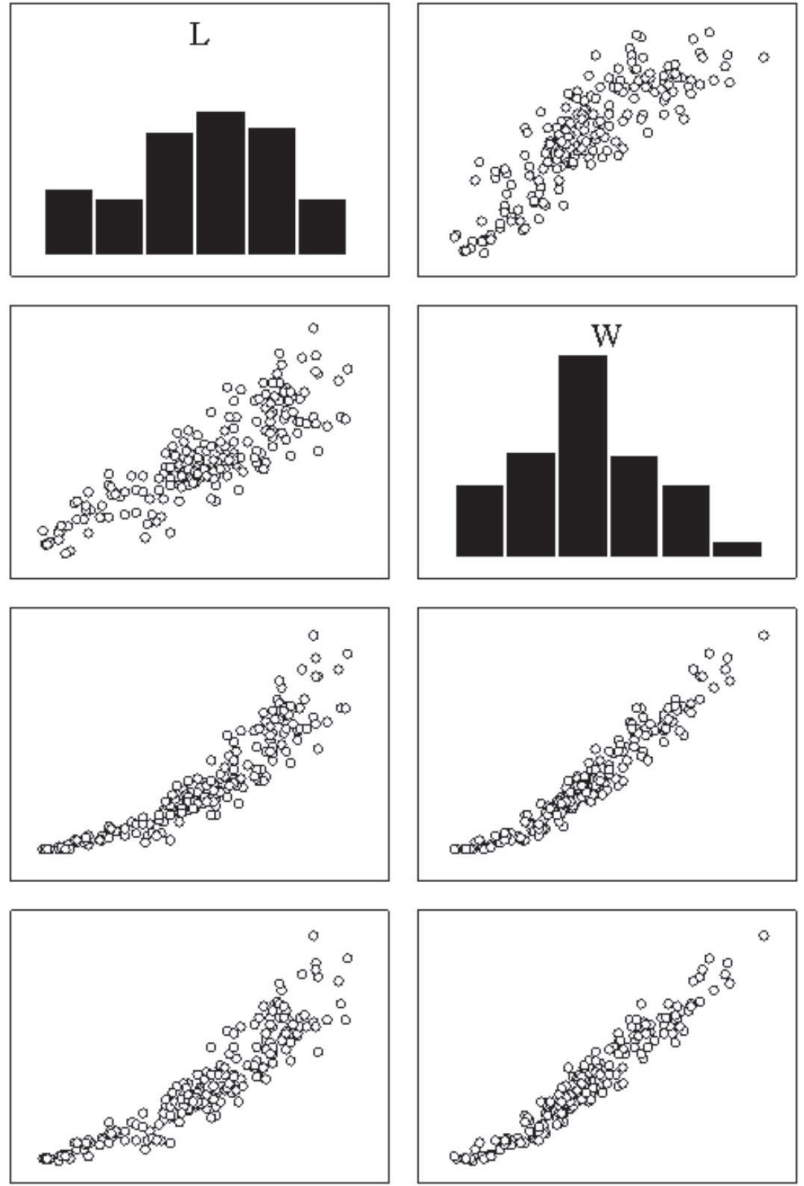

The regression models relating leaf length (L), leaf width (W) and their product ( $\mathrm{LxW}$ ) for the leaf area (LA) were evaluated (Table 3). All models estimated the leaf area of lisianthus with determination coefficients $\left(\mathrm{R}^{2}\right)$ above 0.8374 , with BIAS between 3.4207 and -1.6038 . This indicates that $83.74 \%$ of the variation observed in the leaf area of this species is explained by the proposed model using linear dimensions of the leaves.

Equations highlighted with asterisk had an estimated difference significantly different from zero (biased) for lisianthus leaf area estimation (Figure 3). The linear model

Table 2: Percentage distribution of the real leaf area (LA) Eustoma grandiflorum leaves, in relation to different size ranges

\begin{tabular}{lc}
\hline $\mathbf{L A}\left(\mathbf{c m}^{2}\right)$ & $\boldsymbol{( \% )}$ \\
\hline$[1.01-20.00]$ & 18.0 \\
{$[20.01-40.00]$} & 12.0 \\
{$[40.01-60.00]$} & 22.5 \\
{$[60.01-80.00]$} & 14.5 \\
{$[80.01-100.00]$} & 10.0 \\
{$[100.01-130.00]$} & 16.5 \\
{$[130.01-160.00]$} & 4.0 \\
{$[160.01-190.00]$} & 2.5 \\
\hline
\end{tabular}
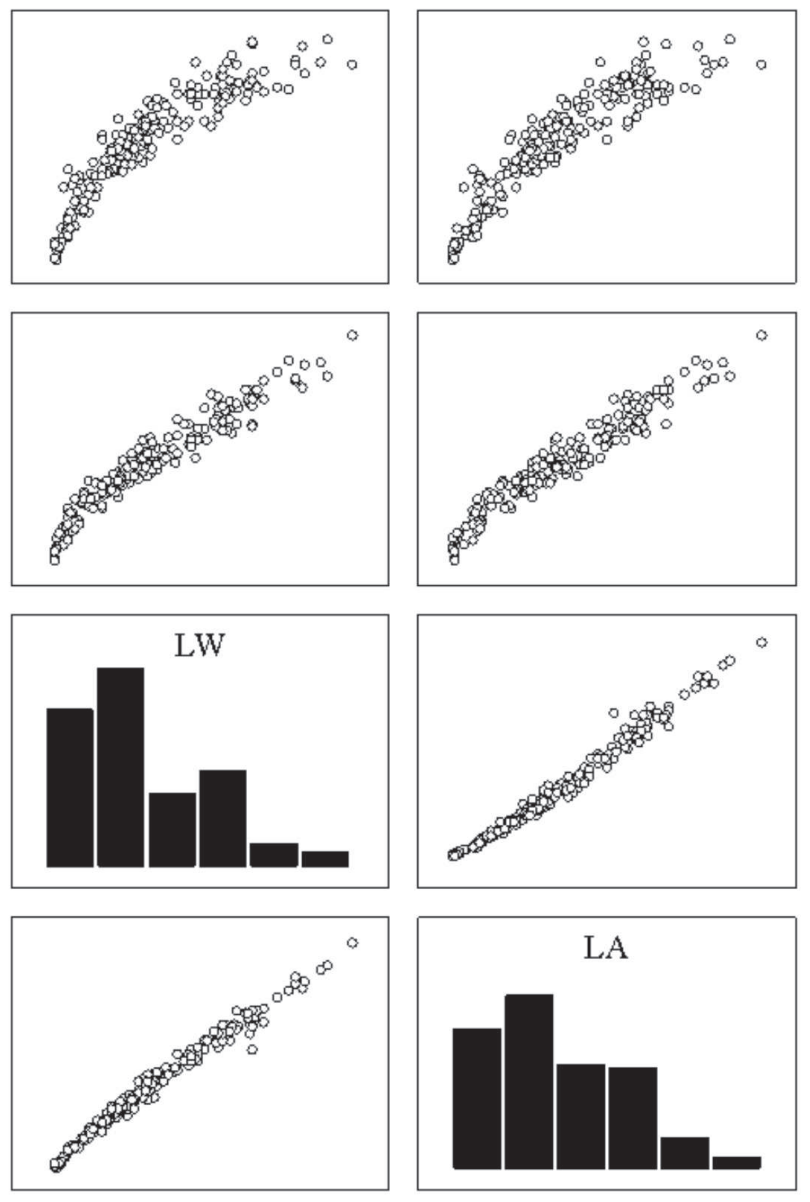

Figure 2: Histograms between leaf length (L), leaf width (W), product of length and width (LW) and leaf area (LA) of Eustoma grandiflorum leaves. 
without intercept, using the product between of length and width ( $\mathrm{LxW}$ ) obtained the highest value of $\mathrm{R}^{2}(0.9925)$ and $d(0.9967)$, in addition to the lowest value for RMSE (4.786), value of AIC (1203.83) (Table 3). Thus, the equation $\mathrm{W}=1.387 * \mathrm{LW}$ constructed from this model is the most suitable to estimate the area in a satisfactory way to that of lisianthus, presenting the best adjustments. Similar results were obtained in studies with Macadamia integrifolia (Schmildt et al., 2016) and Theobroma cacao (Schmildt et al., 2017).

Low dispersion in relation to the adjustment curve was observed, indicating that the models mentioned satisfactorily estimate the real leaf area of lisianthus (Figure 2). The identified model is of great value for studies involving plants, because through the knowledge on leaf area it is possible to analyze the growth, development,

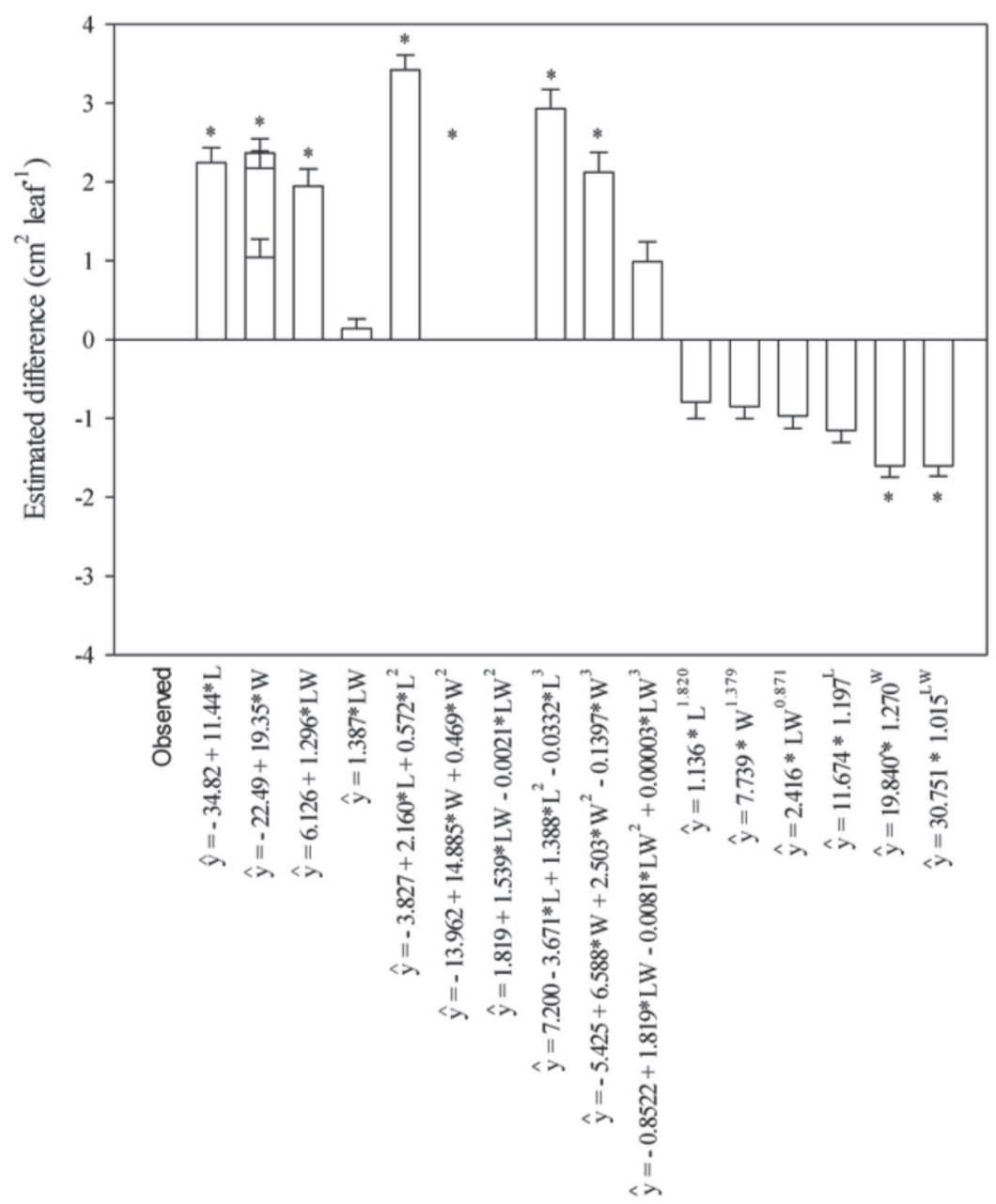

Figure 3: Statistical analysis of the deviation of the estimated area from the observed area. Leaf area of Eustoma grandiflorum was estimated using several models in which b0 and b1 were coefficients. Vertical bars $=$ means; preads $=95 \%$ confidence intervals of the difference; $\mathrm{L}=$ length; $\mathrm{W}=$ width.
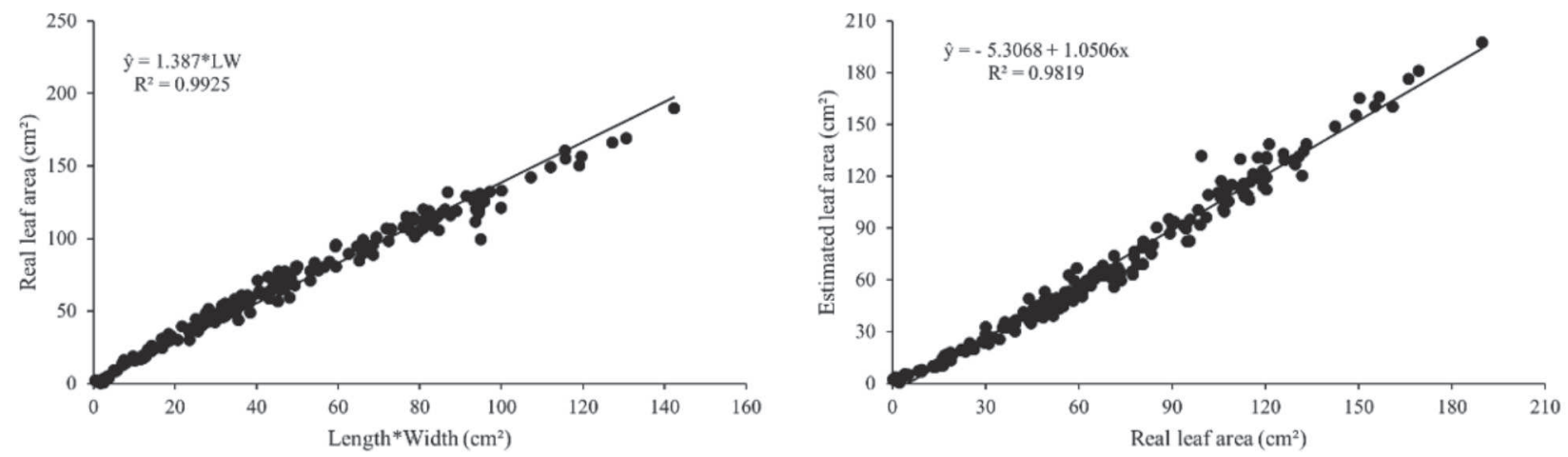

Figure 4: Relationship between real leaf area and length $\mathrm{x}$ width (A) and relationship between estimated leaf area and real leaf area (B).

Rev. Ceres, Viçosa, v. 69, n.1, p. 007-012, jan/feb, 2022 


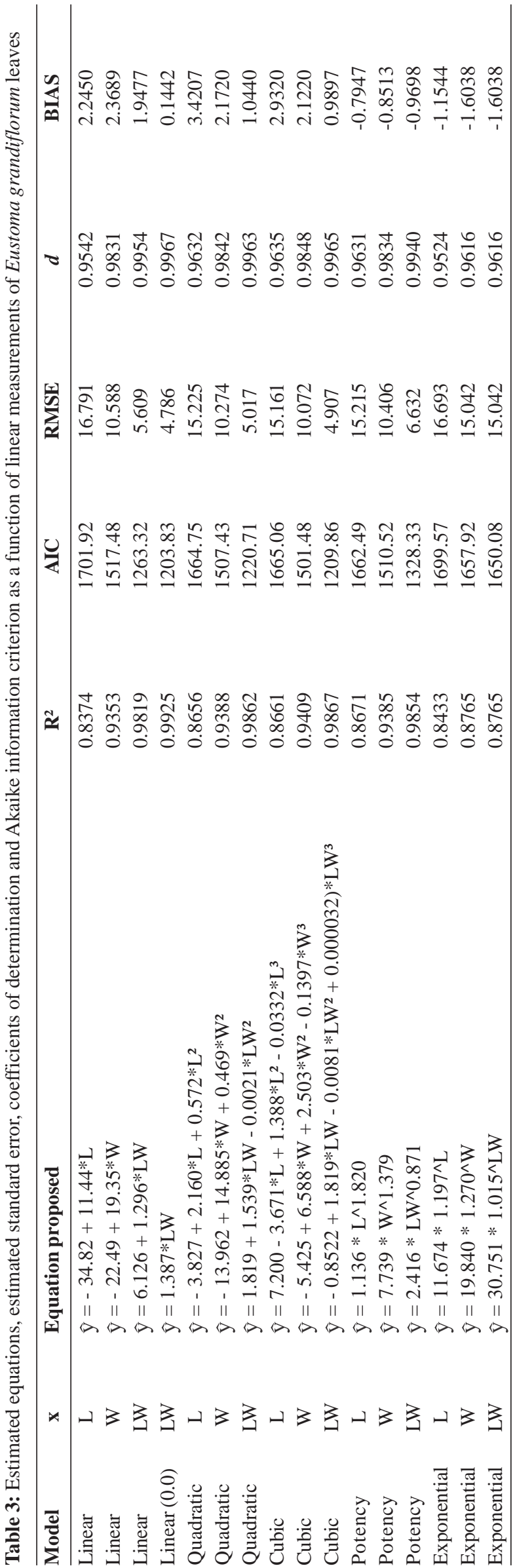

photosynthetic rates, in addition to studies on shading, landscape capacity and ecology of the species which are of great importance the studies of ornamental plants (Gao et al., 2012).

The relationship between real leaf area and length $x$ width and the relationship between estimated leaf area and real leaf area were measured (Figure 4A and B). The estimated leaf area of lisianthus obtained by the model $(\mathrm{LA}=1.387 * \mathrm{LW})$ allows a satisfactory proximity of the real leaf area, since the coefficient of determination was 0.9818 (Figure 4B). With this, the use of accurate equations for lisianthus leaf area estimation using leaf area measurement and their comparison with real leaf area is a methodology as efficient as the destructive methods. Similar patterns were observed in Raphanus sativus L. (Cargnelutti et al., 2012a), Brassica napus L. and Cajanus cajan L. (Cargnelutti et al., 2015a e 2015b). As in Solanum melongena, the models that used the product of length and width were better in estimating the leaf area than those that used the two measures separately (Hinnah et al., 2014).

\section{CONCLUSIONS}

The leaf area of lisianthus can be estimated satisfactorily by a non-destructive method that uses linear measurements of leaves. Many models presented values adjusted to the parameters, but the most adequate to estimate the leaf area of lisianthus was $\mathrm{w}=1.387 * \mathrm{LW}$.

\section{ACKNOWLEDGEMENTS, FINANCIAL SUPPORT AND FULL DISCLOSURE}

The authors would like to thank to Conselho Nacional de Desenvolvimento Científico e Tecnológico (CNPq) and to Coordenação de Aperfeiçoamento de Pessoal de Nível Superior (financing code 001) by scholarships awarded to the authors and to Empresa de Pesquisa Agropecuária de Minas Gerais (EPAMIG).

The authors have no conflict of interest to declare.

\section{REFERENCES}

Akaike H (1974) A new look at the statistical model identification. IEEE Transactions on Automatic Control, 19:716-723.

Azevedo AM, Silveira VA, Oliveira CM, Pedrosa CE, Lemos VT, Valadares NR \& Guimarães AG (2019) Predição da área foliar em acerola por redes neurais e regressão múltipla. Revista Agrária Acadêmica, 2:96-105.

Bertoldo C, Gilardi G, Spadaro D, Gullino ML \& Garibaldi A (2015) Genetic diversity and virulence of Italian strains of Fusarium oxysporum isolated from Eustoma grandiflorum. European Journal of Plant Pathology, 141:83-97.

Cargnelutti FA, Toebe M, Alves BM \& Burin C (2015b) Estimativa da área foliar de feijão guandu por dimensões foliares. Ciência Rural, 45:1-8.

Cargnelutti FA, Toebe M, Alves BM, Burin C \& Kleinpaul JA (2015a) Estimação da área foliar de canola por dimensões foliares. Bragantia, 74:139-148. 
Cargnelutti FA, Toebe M, Burin C, Fick AL \& Casarotto G (2012a) Estimativa da área foliar de nabo forrageiro em função de dimensões foliares. Bragantia, 71:47-51.

Cargnelutti FA, Toebe M, Burin C, Fick AL, Neu IMM \& Facco G (2012b) Estimação da área foliar de mucuna cinza por meio de método não destrutivo. Ciência Rural, 42:238-242.

Castillo-González AM, Avitia-García E, Valdez-Aguilar LA \& Velázquez-Maldonado J (2017) Extracción nutrimental en lisianthus (Eustoma grandiflorum [Raf.] Shinn) cv. Mariachi Pink. Revista Mexicana de Ciencias Agrícolas, 8:345-354.

Francisco JP, Diotto AV, Folegatti MV, Silva LDB \& Piedade SMS (2014) Estimativa da área foliar do abacaxizeiro cv. Vitória por meio de relações alométricas. Revista Brasileira de Fruticultura, 36:285-293.

Gao M, Van der Heijden GWAM, Vos J, Eveleens BA \& Marcelis LFM (2012) Estimation of leaf area for large scale phenotyping and modeling of rose genotypes. Scientia horticulturae, 138:227-234.

Hernandez SV, Fernandez JE, Cuevas MV, Perez MA \& Diaz ESA (2017) Photosynthetic limitations by water deficit: effect on fruit and olive oil yield, leaf area and trunk diameter and its potential use to control vegetative growth of super-high density olive orchards. Agricultural Water Management, 184:9-18.

Hinnah FD, Heldwein AB, Maldaner IC, Loose LH, Lucas DDP \& Bortoluzzi MP (2014) Estimation of eggplant leaf area from leaf dimensions. Bragantia, 73:213-218.

Janssen PHM \& Heuberger PSC (1995) Calibration of processoriented models. Ecological Modelling, 83:55-66.

Leite HG \& Andrade VCL (2002) Um método para condução de inventários florestais sem o uso de equações volumétricas. Revista Árvore, 26:321-328.

Leite MLMV, Lucena LRR, Sá Júnior EH \& Cruz MG (2017) Estimativa da área foliar em Urochloa mosambicensis por dimensões lineares. Revista Agropecuária Técnica, 38:9-16.

Levine DM, Berenson ML, Krehbiel TC \& Stephan D (2012) Estatística: teoria e aplicações usando Microsoft Excel em português. $6^{\text {th }}$ ed. Rio de Janeiro, LTC Editora. 832p.

Maia CE, Silva NJM \& Braga AQC (2020) Estimativa da área foliar do meloeiro irrigado em função do número de folhas. Revista Ibero-Americana de Ciências Ambientais, 11:85-91.

Mattos EM, Binkley D, Campoe OC, Alvares CA \& Stape JL (2020) Variation in canopy structure, leaf area, light interception and light use efficiency among Eucalyptus clones. Forest Ecology and Management, 463:118038.

Morgado MAD, Bruckner CH, Rosado LDS, Assunção W \& Santos CEM (2013) Estimação da área foliar por método não destrutivo, utilizando medidas lineares das folhas de espécies de Passiflora. Revista Ceres, 60:662-667.

$\mathrm{R}$ development core team (2020) R: A language and environment for statistical computing. Vienna, R Foundation for Statistical Computing. Available at: https://www.r-project.org/. Accessed on: November $15^{\text {th }}, 2020$.
Ribeiro JES, Barbosa AJS \& Albuquerque MB (2018) Leaf area estimate of Erythroxylum simonis plowman by linear dimensions. Floresta e Ambiente, 25:1-7.

Ribeiro JES, Figueiredo FRA, Coêlho EDS, Pereira WE \& Albuquerque MBD (2020) Leaf area estimation of Palicourea racemosa (Aubl.) Borhidi from linear measurements. Floresta e Ambiente, 27:e20180105.

Schmildt ER, Amaral JAT, Schmildt O \& Santos JS (2014) Análise comparativa de equações para estimativa da área foliar em cafeeiros. Coffee Science, 9:155-167.

Schmildt ER, Hueso JJ, Pinillos V, Stellfeldt A \& Cuevas J (2017) Allometric models for determining leaf area of' Fino de Jete' cherimoya grown in greenhouse and in the open field. Fruits, 72:24-30

Schmildt ER, Negris FS, Cesana JE, Schmildt O \& Alexandre RS (2016) Equações para estimar área foliar de maracujá-amarelo. Nucleus, 13:97-104.

Schmildt ER, Oliari LS, Schmildt O, Alexandre RS, Brumatti JÁ \& Viana DG (2016) Determinação da área foliar de macadâmia a partir de dimensões lineares do limbo foliar. Revista Agro@mbiente, 10:209-216.

Schmildt ER, Trevisan E, Belique M \& Schmildt O (2017) Modelos alométricos para determinação da área foliar de cacaueiro 'PH-16' em sombreamento e pleno sol. Revista Agroambiente, $11: 47-55$

Schwab NT, Streck NA, Rehbein A, Ribeiro BSMR, Ulhmann LO, Langner JA \& Becker CC (2014) Dimensões lineares da folha e seu uso na determinação do perfil vertical foliar de gladíolo. Bragantia, 73:97-105.

Silva SF, Cabanez PA, Mendonça RF, Pereira LR \& Amaral JAT (2015) Modelos alométricos para estimativa da área foliar de mangueira pelo método não destrutivo. Revista Agro@mbiente, 9:86-90.

Silva SF, Pereira LR, Cabanez PA, Mendonça RF \& Amaral JAT (2017) Modelos alométricos para estimativa da área foliar de boldo pelo método não destrutivo. Agrarian, 10:193-198.

Souza ALP, Costa MM, Sena JDG \& Paz RBO (2019) Avaliação de três métodos de obtenção do índice de área foliar para cultura da soja. Nativa, 7:284-287.

Toebe M, Cargnelutti FA, Burin C, Fick AL, Neu IMM, Casarotto G \& Alves BM (2012) Modelos para a estimação da área foliar de feijão de porco por dimensões foliares. Bragantia, 71:37-41.

Willmott CJ, Ackleson SG, Davis RE, Feddema JJ, Klink KM, Legates DR, O'Donnell J \& Rowe CM (1985) Statistics for the evaluation and comparison of models. Journal of Geophysical Research: Oceans, 90:8995-9005.

Zeist AR, Oliveira JRF, Lima FRB, Silva MLS \& Resende JTV (2014) Comparação de métodos de estimativa de área foliar em morangueiro. Pesquisa Agropecuária Gaúcha, 20:33-40. 